\title{
Persistent Risk for Hepatocellular carcinoma in patients on antiviral treatment: A Need for HBV cure
}

\author{
Joseph Yoo ${ }^{1}$, Grace Park ${ }^{1,2}$, Richard S Hann ${ }^{2}$ and Hie-Won Hann ${ }^{1,2 *}$ \\ ${ }^{1}$ Division of Gastroenterology and Hepatology, Department of Medicine, Sidney Kimmel Medical College, Thomas Jefferson University Hospital, USA \\ ${ }^{2}$ Liver Disease prevention Center, Division of Gastroenterology and Hepatology, Department of Medicine, Sidney Kimmel Medical College, Thomas Jefferson \\ University Hospital, USA
}

During the past 20 years, with the advent of highly effective antiviral drugs for Hepatitis B virus (HBV), we have witnessed successful viral suppression as well as the delay and prevention of progressive liver disease leading to cirrhosis and hepatocellular carcinoma (HCC).

In the past, reduced incidence of HCC with antiviral treatment has been well documented with lamivudine, entecavir and tenofovir [1-4]

Furthermore, prevention of recurrent HCC was observed by numerous investigators including ours following initial tumor ablation when patients received combined antiviral treatment [5-10].

Nonetheless, as reported previously, we are observing a persistent risk for HCC in patients who have maintained successful suppression of viral replication with undetectable serum HBV DNA and normal liver function, even in patients who have been on anti-HBV therapy for greater than 18 years [11]. The duration of anti-HBV treatment for these patients ranged from 9.3 to 18.4 years (highlighted). Patients remained with undetectable serum HBV DNA for 6.7-12.4 years (highlighted) before developing their first HCC. The result of the observation is shown in table 1 [11].

In addition, among patients who are on antiviral therapy and post first tumor ablation, some of them continue developing new $\mathrm{HC}$ or recurrent HCC several years (5-10 years) after the first HCC (personal communication). In most cases, however, continued antiviral therapy and additional tumor ablation has been successful and patients remain well on continued antiviral treatment.

These persistent risks for new and recurrent HCC among patients with successful control of $\mathrm{HBV}$ are attributed to the incomplete control of HBV, namely due to the presence of cccDNA in the host's hepatocytes.

While we are able to achieve a functional cure, a complete cure that is able to eliminate the cccDNA has not yet been possible. Therefore, even though HBV is not actively replicating, cccDNA remains in the nucleus of the hepatocytes and continues hepatocarcinogenic process including HBV and host DNA integration.

While we are grateful for the current management of HBV associated HCC, there is a desperate need for the drugs that can eradicate the virus.

Due to the complexity of HBV replication, it has not been easy. However, there are several potential strategies, some of which are already in clinical trials. Preventing the virus from entering the new hepatocytes is considered one of the important steps. Recently the entry receptor was discovered to be sodium taurocholate co-transporting polypeptide (NTCP) $[12,13]$. And the entry inhibitors that target the NTCP receptor can prevent de novo infection of hepatocytes by the HBV. One of the entry inhibitor is called Myrcludex-B which is a myristoylated PreS1 peptide. Currently the Myrcludex-B is in phase II clinical trial [14], Prevention of the replication of new HBV DNA from the pregenomic RNA has been successful with currently available nucleos(t)ide analogues. Enhancing the host innate immunity has been tried with small molecule agonists of toll-like receptors (TLR) and currently in clinical trials with TLR-7 and TLR-9. A therapeutic vaccine engineered to activate an HBV-specific $\mathrm{T}$ cell immune response is in early stage of the clinical trial. Also, direct-acting antivirals to target HBV has been in early stage of clinical trial. Little is known how

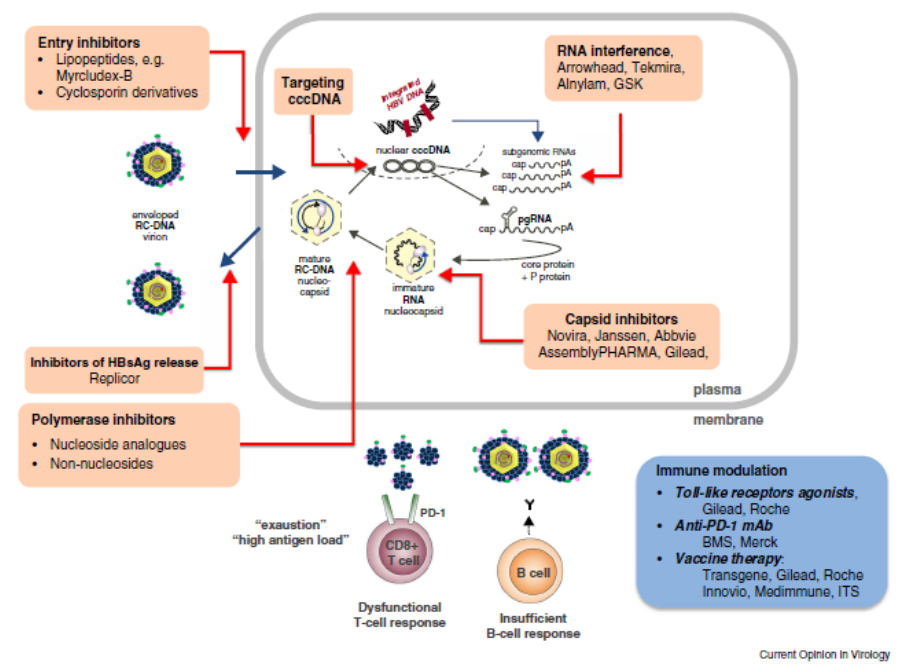

Figure 1. The landscape of HBV cure efforts.

All steps of the HBV replication cycle (virus entry, cccDNA formation, chromatinization and transcription, viral mRNAs, envelope protein secretion, core protein and the capsid, pol enzymatic activities), the intrahepatic innate immune responses and the deficient adaptive HBV specific B and T cell responses are currently being explored as potential new therapeutic targets (Lavrero et al. [15]).

${ }^{\star}$ Correspondence to: Hie-Won Hann, Division of Gastroenterology and Hepatology, Department of Medicine, Sidney Kimmel Medical College, Thomas Jefferson University Hospital, Philadelphia, PA, 19107 USA, E-mail: hie-won.hann@jefferson.edu

Key words: $H B V$, antiviral drugs, HCC, HBV cure

Received: May 04, 2018; Accepted: May 25, 2018; Published: May 28, 2018 
Table 1. Development of HCC in patients with cirrhosis on long-term antiviral therapy [11]*

\begin{tabular}{|c|c|c|c|c|c|c|c|c|c|}
\hline $\begin{array}{c}\mathbf{P t} \\
\#\end{array}$ & $\begin{array}{l}\text { Treatment } \\
\text { Start }\end{array}$ & $\begin{array}{l}\text { Anti-HBV } \\
\text { treatment }\end{array}$ & $\begin{array}{c}\text { HCC } \\
\text { Diagnosis }\end{array}$ & $\begin{array}{l}\text { Years on anti- } \\
\text { HBV therapy at } \\
\text { HCC diagnosis }\end{array}$ & $\begin{array}{c}\text { Years with } \\
\text { undetectable } \\
\text { HBV DNA } \\
\text { before HCC } \\
\text { diagnosis }\end{array}$ & $\begin{array}{l}\text { Size }(\mathrm{cm}) \text { and } \\
\text { site of } \mathrm{HCC}\end{array}$ & $\begin{array}{c}\text { HBV DNA at } \\
\text { HCC } \\
\text { diagnosis }\end{array}$ & $\begin{array}{l}\text { Sex and Age (yr) } \\
\text { at HCC Dx }\end{array}$ & Status \\
\hline 1 & May 1998 & $\mathrm{LAM}+\mathrm{TDF}$ & February 2008 & 9.8 & 6.7 & $\begin{array}{c}1.8 \mathrm{x} 0.9 \\
\mathrm{Lt}\end{array}$ & UD & $76 \mathrm{~F}$ & alive \\
\hline 2 & February 2004 & TDF & June 2013 & 9.3 & 7.7 & $\begin{array}{c}2.5 \\
\mathrm{Lt}\end{array}$ & UD & $57 \mathrm{M}$ & dead \\
\hline 3 & $\begin{array}{c}\text { February } \\
1996\end{array}$ & $\mathrm{TDF}$ & July 2013 & 17.4 & 9.7 & $\begin{array}{c}1.6 \times 1.4 \\
\mathrm{Rt}\end{array}$ & UD & $73 \mathrm{M}$ & alive \\
\hline 4 & May 1996 & $\mathrm{LAM}+\mathrm{TDF}$ & October 2014 & 18.4 & 10.4 & $\begin{array}{l}3.4 \\
\mathrm{Rt}\end{array}$ & UD & $74 \mathrm{M}$ & alive \\
\hline 5 & February 2000 & TDF & April 2015 & 15.2 & 12.4 & $\begin{array}{c}3.4 \times 3.4 \\
\mathrm{Rt}\end{array}$ & UD & $62 \mathrm{M}$ & alive \\
\hline
\end{tabular}

HCC: Hepatocellular Carcinoma, HBV: Hepatitis B Virus, LAM: Lamivudine, TDF: Tenofovir Disoproxil Fumarate.

Average years on antiviral therapy: average 14 years with a median of 15.2 years (9.3-18.4 years): Average years with undetectable HBV DNA:

median 9.7 years $(6.7-12.4$ years).

*From Minerva Gastroenterol Dietol 2017; 63: 74-76. [11].

cccDNA is formed and regulated. Knowledge of this process would be crucial in the effort of $\mathrm{HBV}$ cure. Also direct targeting cccDNA is highly desired and it is hoped to become available in the near future

Recent update of the development of potential HBV cure drugs was recently presented by Levrero et al. [15] and Block et al. [16].

The lucidly illustrated "the landscape of HBV cure efforts" by Levrero et al. is shown below [16]. The chart clearly reveals the potential treatment strategies in the future (Figure 1).

\section{References}

1. Liaw YF, Sung JJ, Chow WC, Farrell G, Lee CZ, et al. (2004) Lamivudine for patients with chronic hepatitis B and advanced liver disease. N Engl J Med 351: 1521-1531. [Crossref]

2. Eun JR, Lee HJ, Kim TN, Lee KS (2010) Risk assessment for the development of hepatocellular carcinoma: to on-treatment viral response during long-term lamivudine therapy in hepatitis B virus related liver disease. J Hepatol 53: 118-125. [Crossref]

3. Hosaka T, Suzuki F, Kobayashi M, Seko Y, Kawamura Y, et al. (2013) Long-term entecavir treatment reduces hepatocellular carcinoma incidence in patients with hepatitis B virus infection. Hepatology 58: 98-107. [Crossref]

4. Kim WR, Loomba R, Berg T, Aguilar Schall RE, Yee LJ, et al. (2015) Impact of longterm tenofovir disoproxil fumarate on incidence of hepatocellular carcinoma in patients with chronic hepatitis B. Cancer 121: 3631-3638. [Crossref]

5. Kubo S,Tanaka H, Takemura S, Yamamoto S, Hai S, et al. (2007) Effects of lamivudine on outcome after liver resection for hepatocellular carcinoma in patients with active replication of hepatitis B virus. Hepatol Res 37: 94-100. [Crossref]

6. Huang G, Lau WY, Wang ZG, Pan ZY, Yuan SX, et al. (2015) Antiviral therapy improves postoperative survival in patients with hepatocellular carcinoma: a randomized controlled trial. Ann Surg 261: 56-66. [Crossref]
7. Yin J, Li N, Han Y, Xue J, Deng Y, et al. (2013) Effect of antiviral treatment with nucleotide/nucleoside analogs on postoperative prognosis of hepatitis B virus-related hepatocellular carcinoma: a two-stage longitudinal clinical study. J Clin Oncol 31: 3647-3655. [Crossref]

8. Chuma M, Hige S, Kamiyama T, Meguro T, Nagasaka A, et al. (2009) The influence of hepatitis B DNA level and antiviral therapy on recurrence Canadian Journal of Gastroenterology and Hepatology 11 after initial curative treatment in patients with hepatocellular carcinoma. J Gastroenterol 44: 991-999. [Crossref]

9. Wu JCY, Chen YJ, Ho HJ, Hsu YC, Kuo KN, et al. (2012) Association between nucleoside analogues and risk of hepatitis B virus-related hepatocellular carcinoma recurrence following liver resection. JAMA 308: 1906-1914. [Crossref]

10. Hann HW, Coben R, Brown D, Needleman L, Rosato E, et al. (2014) A long-term study of the effects of antiviral therapy on survival of patients with HBV-associated hepatocellular carcinoma (HCC) following local tumor ablation. Cancer Med 3: 390-396. [Crossref]

11. Dargan A, Wong SY, Coben R, Conn M, Dimarino AJ, et al. (2017) Persistent risk for hepatocellular carcinoma after more than a decade of successful hepatitis B virus suppression. Minerva Gastroenterol Dietol 63: 74-76. [Crossref]

12. Yan H, Zhong G, Xu G, He W, Jing Z, et al. (2012) Sodium taurocholate cotransporting polypeptide isa functional receptor for human hepatitis B and D virus. eLife 1: e00049. [Crossref]

13. Ni Y, Lempp FA, Mehrle S, Nkongolo S, Kaufman C, et al. (2014) Hepatitis B and $\mathrm{D}$ viruses exploit sodium taurocholate co-transporting polypeptide for species-specific entry into hepatocytes. Gastroenterology 146: 1070-1083. [Crossref]

14. Urban S, Bartenschlager R, Kubitz R, Zoulim F (2014) Strategies to inhibit entry of $\mathrm{HBV}$ and HDV into hepatocytes. Gastroenterology 147: 48-64. [Crossref]

15. Levrero M, Testoni B, Zoulim F (2016) HBV cure: why, how, when? Curr Opin Virol 18: 135-143. [Crossref]

16. Block TM, Alter H, Brown N, Brownstein A, Brosgart C, et al. (2018) Research priorities for the discovery of a cure for chronic hepatitis B: Report of a workshop. Antiviral Res 150: 93-100. [Crossref]

Copyright: (C2018 Yoo J. This is an open-access article distributed under the terms of the Creative Commons Attribution License, which permits unrestricted use, distribution, and reproduction in any medium, provided the original author and source are credited. 